\section{Sand Topdressing Applications Improve Shear Strength and Turfgrass Density on Trafficked Athletic Fields}

\author{
Alexander R. Kowalewski ${ }^{1,4}$, John N. Rogers, III' ${ }^{2}$, James R. Crum², \\ and Jeffrey C. Dunne ${ }^{3}$
}

\begin{abstract}
AdDitional Index wORDs. turf, Poa pratensis, Lolium perenne, density, wear tolerance, sandy loam

SUMMARY. Drain tile installation into a native-soil athletic field and subsequent sand topdressing applications are cost-effective alternatives to complete field renovation. However, if cumulative topdressing rates exceed root system development, surface stability may be compromised. The objective of this research was to evaluate the effects of cumulative topdressing, over a compacted sandy loam soil, on the fall wear tolerance and surface shear strength of a kentucky bluegrass (Poa pratensis) perennial ryegrass (Lolium perenne) stand. Research was initiated in East Lansing, MI, on 10 Apr. 2007. A well-graded, high-sand-content root zone $(90.0 \%$ sand, $7.0 \%$ silt, and $3.0 \%$ clay) was topdressed at a 0.25 -inch depth $\left[2.0 \mathrm{lb} / \mathrm{ft}^{2}\right.$ (dry weight)] per application, providing cumulative topdressing depths of $0.0,0.5,1.0$, 1.5, or 2.0 inches applied from 11 July to 15 Aug. 2007. Fall traffic was applied twice weekly to all treatments from 10 Oct. to 3 Nov. 2007. In 2008, topdressing applications and traffic, as described earlier, were repeated on the same experimental plots. Results obtained from this research suggest that the 0.5 -inch topdressing depth applied over a 5-week period in the summer will provide improved shoot density and surface shear strength in the subsequent fall. Results also suggest that topdressing rates as thick as 4.0 inches accumulated over a 2 -year period will provide increased shoot density, but diminished surface shear strength.
\end{abstract}

A thletic fields high in silt and clay are susceptible to compaction during periods of substantialrainfall combined with heavy use (Benson and Daniel, 1990), typical of a fall or spring athletic season in the midwestern United States. The stresses associated with compaction can reduce turfgrass quality, percentage of cover, total nonstructural carbon, shoot density, verdure, and root growth (Carrow, 1980).

Sand has a relatively large volume of macropore space and is inherently low in silt and clay, allowing it to maintain a large proportion of macropore space when subjected to compactive forces (Bingaman and Kohnke, 1970). A relatively large volume of macropore

This study is a portion of a dissertation submitted by Alexander R. Kowalewski in fulfillment of Philosophical Doctorate degree requirements.

${ }^{1}$ Department of Environmental Horticulture, 139 Environmental Horticulture Building, Abraham Baldwin Agricultural College, Tifton, GA 31794

${ }^{2}$ Department of Crop and Soil Sciences, Al60 Plant and Soil Science Building, Michigan State University, East Lansing, MI 48824

${ }^{3}$ Department of Crop and Soil Sciences, Al62 Plant and Soil Science Building, Michigan State University, East Lansing, MI 48824

${ }^{4}$ Corresponding author. E-mail: kowalew8@msu.edu. space allows for rapid water infiltration, which makes sand a desirable and advantageous media for athletic field construction (Henderson et al., 2005a). However, complete field renovation to a sand-based system is expensive and renders the field temporarily unusable. High school athletic fields usually have high use requirements in the spring and fall. This restricts renovation to the summer months if the intention is to keep the field in play. Because of these drawbacks, complete field renovation is not an option for municipalities with high annual use requirements and limited budgets.

Developing a sand-cap athletic field system over time using sand topdressing is a possible alternative to complete field renovation as it does not take the field completely out of play. Sand topdressing of athletic fields has been recommended for the improvement of native-soil systems and the sustenance of sand-based systems and incorporated into maintenance practices for many years (Baker and Canaway, 1992; Beard, 1978; Liebao and Aldous, 1999; Puhalla et al., 1999). Research has shown that sand topdressing can be used to modify the soil texture, dilute soil organic matter, and smooth the surface of a turfgrass system. For instance, Miller (2008) determined that three sand topdressing applications applied over a 5-month period, totaling a $0.6-\mathrm{cm}$ topdressing depth, increased surface hardness, stand density, and rooting of a bermudagrass (Cynodon dactylon) turfgrass stand maintained at a $2.5-\mathrm{cm}$ height and subjected to intense traffic. McCarty et al. (2005) determined that an annual topdressing depth of $0.12 \mathrm{~cm}$ improved infiltration rates of a 'L-93' creeping bentgrass (Agrostis stolonifera) stand maintained at 0.3 to $0.4-\mathrm{cm}$ height, in comparison with treatments that did not receive topdressing. Barton et al. (2009) demonstrated that topdressing, twice annually at a $0.5-\mathrm{cm}$ topdressing depth, increased the color of a kikuyugrass (Pennisetum clandestinum) stand maintained at $1.5-\mathrm{cm}$ height, in comparison with treatments that did not receive topdressing or cultivation. Spring et al. (2007) showed that 8.0 to $12.0 \mathrm{~kg} \cdot \mathrm{m}^{-2}$ of sand topdressing per year improved perennial ryegrass cover, soccer ball bounce, and traction after simulated wear was applied using a slip wear machine (Canaway, 1976). Research conducted by Baker and Canaway (1992) observed that the highest sand topdressing rate, $16.0 \mathrm{~kg} \cdot \mathrm{m}^{-2}$ per year, produced the greatest perennial

\begin{tabular}{llll}
\hline $\begin{array}{l}\text { Units } \\
\begin{array}{l}\text { To convert U.S. to SI, } \\
\text { multiply by }\end{array}\end{array}$ & U.S. unit & SI unit & $\begin{array}{l}\text { To convert SI to U.S., } \\
\text { multiply by }\end{array}$ \\
\hline 0.3048 & $\mathrm{ft}$ & $\mathrm{m}$ & 3.2808 \\
0.0929 & $\mathrm{ft}^{2}$ & $\mathrm{~m}^{2}$ & 10.7639 \\
2.54 & inch $(\mathrm{es})$ & $\mathrm{cm}$ & 0.3937 \\
25.4 & inch $(\mathrm{es})$ & $\mathrm{mm}$ & 0.0394 \\
6.4516 & inch & $\mathrm{cm}^{2}$ & 0.1550 \\
48.8243 & $\mathrm{lb} / 1000 \mathrm{ft}^{2}$ & $\mathrm{~kg} \cdot \mathrm{ha}^{-1}$ & 0.0205 \\
4.8824 & $\mathrm{lb} / \mathrm{ft}^{2}$ & $\mathrm{~kg} \cdot \mathrm{m}^{-2}$ & 0.2048 \\
1.3558 & $\mathrm{lb} \mathrm{ft}$ & $\mathrm{N} \cdot \mathrm{m}^{-2}$ & 0.7375 \\
1.7300 & $\mathrm{Oz} / \mathrm{inch}^{3}$ & $\mathrm{~g} \cdot \mathrm{cm}^{-3}$ & 0.5780 \\
1 & $\mathrm{ppm}$ & $\mathrm{mg} \cdot \mathrm{kg}^{-1}$ & 1 \\
$\left({ }^{\circ} \mathrm{F}-32\right) \div 1.8$ & ${ }^{\circ} \mathrm{F}$ & ${ }^{\circ} \mathrm{C}$ & $\left(1.8 \times{ }^{\circ} \mathrm{C}\right)+32$
\end{tabular}


ryegrass playing quality, ball rebound resilience, traction, and surface hardness. Research conducted by Baker et al. (2007) demonstrated that topdressing perennial ryegrass with sand is a more cost-effective maintenance practice (cost in relation to playing surface quality) than the cultivation practice used in their research. These findings suggest an array of topdressing rates for single application and cumulative depths.

Increasing the number of annual topdressing applications will decrease the duration of time required to accumulate an adequate root zone over an existing native soil. However, if topdressing application rates exceed root system development, surface stability may be reduced. Therefore, developing an optimum topdressing regime capable of accumulating an adequate root zone layer, without being detrimental to turfgrass wear tolerance or surface stability, is critical.

The objective of this research was to evaluate the effects of cumulative sand topdressing rates, over a compacted sandy loam, on the fall wear tolerance and surface shear strength of a cool-season turfgrass stand. The initial hypothesis of this research was that topdressing would increase turfgrass wear tolerance characteristics and surface shear strength; however, high amounts of cumulative topdressing applications would reduce these characteristics.

\section{Materials and methods}

Field research was initiated at the Hancock Turfgrass Research Center (HTRC), East Lansing, MI, on 10 Apr. 2007. Experimental design was a randomized complete block design, with three replications. The total experimental area was $1566 \mathrm{ft}^{2}$ and contained 15 plots $\left(32.0 \mathrm{ft}^{2}\right)$, with buffer strips between the plots. Topdressing depths achieved in the first year were $0.0,0.5,1.0,1.5$, and 2.0 inches.

A sandy loam [73.4\% sand $(0.05-$ $2.0 \mathrm{~mm}), 21.2 \%$ silt $(0.002-0.05 \mathrm{~mm})$, and $5.4 \%$ clay $(<0.002 \mathrm{~mm})$; Michigan State University (MSU) Soil and Plant Nutrient Laboratory, East Lansing, $\mathrm{MI}$ ], the A horizon of a Colwood series loam soil (fine-loamy, mixed, active, mesic Typic Endoaquoll) (Natural Resources Conservation Service, 2007), was excavated and then thoroughly mixed to ensure even particle distribution and degrade soil structure. The mixed soil was then placed into a 56.0 -ft-wide $\times 28.0$-ft-long $\times 1.5$-ft-deep research plot, constructed of treated plywood, on the HTRC parking lot, from 16 to 21 Apr. 2007. The soil was irrigated repeatedly and compacted in layers using a vibratory compactor (B1824H vibratory plate compactor; Bartell Morrison, Mississauga, ON, Canada), to compact and simulate a heavily trafficked and poorly drained athletic field. Soil samples were collected and analyzed to determine $\mathrm{pH}$, nutrient levels, bulk density, and saturated hydraulic conductivity $(\mathrm{pH} 7.6$, 149 ppm phosphorus, 127 ppm potassium, bulk density $1.6 \mathrm{~g} \cdot \mathrm{cm}^{-3}$, saturated hydraulic conductivity 0.12 inch $/ \mathrm{h}$ ).

TURfgrass establishment, TOPDRESSING, AND TRAFFIC (2007). Seeding preparation occurred on 23 May 2007 and included core cultivation and starter fertilizer application. Core cultivation was performed using 0.5 -inch-diameter hollow tines on 2.0-inch centers and 2.0-inch depth. The cores were incorporated back into the soil with hand rakes. Starter fertilizer $16 \mathrm{~N}-11.0 \mathrm{P}-10.8 \mathrm{~K}$ (Lebanon Turf Products ${ }^{\mathrm{TM}}$, Lebanon, PA) was applied at $1.0 \mathrm{lb} / 1000 \mathrm{ft}^{2}$ phosphoric oxide $\left(\mathrm{P}_{2} \mathrm{O}_{5}\right)$ (amounting to $4.0 \mathrm{lb} /$ $1000 \mathrm{ft}^{2}$ fertilizer per application) before seeding.

On 29 May 2007, the research plot was seeded with a kentucky bluegrass (19.7\% 'Arcadia', 19.7\% 'Odyssey',
19.6\% 'America', 19.6\% 'SR 2100', and $19.6 \%$ 'Mercury') and perennial ryegrass (34.4\% 'Harrier', 34.1\% 'Peregrine', and 29.8\% 'SR 4600') (Research Seeds, Fort Dodge, IA) mixture, at 1.3 and $0.9 \mathrm{lb} / 1000 \mathrm{ft}^{2}$, respectively, similar to the ratios used by Brede and Duich (1984). Siduron (Lebanon Seaboard $^{\odot}$, Lebanon, PA) was applied at $0.1 \mathrm{lb} / 1000 \mathrm{ft}^{2}$ directly after seeding.

Sand topdressing treatments were initiated on 11 July 2007 and concluded on 15 Aug. 2007, similar to the topdressing practices that would be used on an athletic field that receives heavy use in the spring and fall. A wellgraded, high-sand-content root zone mixture $[90.0 \%$ sand, $7.0 \%$ silt, and $3.0 \%$ clay (Table 1)] developed for athletic field construction (ASTM International, 2006; Henderson et al., 2005a) was applied at a 0.25 -inch topdressing depth $\left[2.0 \mathrm{lb} / \mathrm{ft}^{2}\right.$ (dry weight)] using a mechanical topdresser. $\mathrm{Cu}^{-}$ mulative topdressing depths achieved by 15 Aug. 2007 were 0.0, 0.5, 1.0, 1.5 , and 2.0 inches, depending on the number of applications (Table 2).

The Cady traffic simulator, a modified core cultivation unit (Aero King $30^{\mathrm{TM}}$; Jacobsen $^{\odot}$ Textron, Charlotte, NC) (Henderson et al., 2005b; Vanini et al., 2007) was used to apply two traffic applications (four passes, two forward and two backward) per week, from 10 Oct. to 3 Nov. 2007.

Table 1. Particle size analysis, coefficient of uniformity, coefficient of curvature, bulk density, and saturated hydraulic conductivity of well-graded, ${ }^{\mathrm{z}}$ high-sandcontent root zone.

\begin{tabular}{|c|c|}
\hline Particle size $^{\mathrm{y}}$ & $\begin{array}{c}\text { Sieve fraction sand particle } \\
\text { diam (\% retained })\end{array}$ \\
\hline$>2.0 \mathrm{~mm}$ & 0.3 \\
\hline Very coarse sand (1.0-2.0 mm) & 9.1 \\
\hline Coarse sand $(0.5-1.0 \mathrm{~mm})$ & 19.9 \\
\hline Medium sand (0.25-0.5 mm) & 39.3 \\
\hline Fine sand $(0.1-0.25 \mathrm{~mm})$ & 18.7 \\
\hline Very fine sand $(0.05-0.1 \mathrm{~mm})$ & 2.7 \\
\hline Silt $(0.002-0.05 \mathrm{~mm})$ & 7.0 \\
\hline Clay $(<0.002 \mathrm{~mm})$ & 3.0 \\
\hline$C_{\mathrm{u}}\left(D_{60} / D_{10}\right)^{\mathrm{x}}$ & 8.0 \\
\hline$C_{\mathrm{c}}\left[D_{30}^{2} /\left(D_{60} \times D_{10}\right)\right]^{\mathrm{w}}$ & 2.4 \\
\hline Bulk density ${ }^{\mathrm{y}}$ & $1.8 \mathrm{~g} \cdot \mathrm{cm}^{-3}$ \\
\hline Saturated hydraulic conductivity ${ }^{y}$ & $6.1 \mathrm{inch} / \mathrm{h}$ \\
\hline \multicolumn{2}{|c|}{ 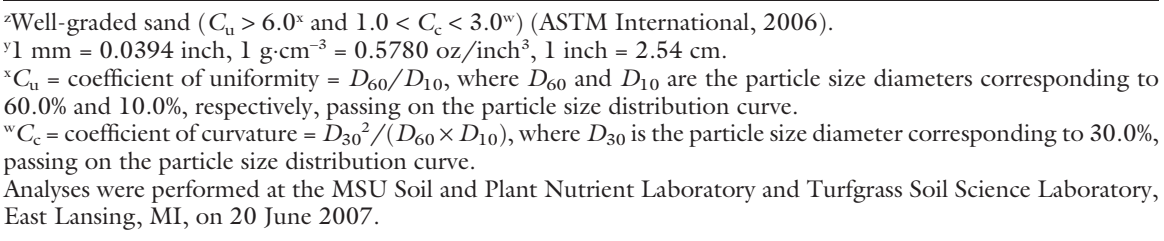 } \\
\hline
\end{tabular}


Turfgrass Re-ESTABLISHMENT, TOPDRESSING, AND TRAFFIC (2008). On 22 Apr. 2008, treatments were core cultivated with 0.5 -inch-diameter hollow tines on 2.0-inch centers and 0.5 -inch depth and interseeded with the same kentucky bluegrass-perennial ryegrass mixture, similar to the procedure used by Rogers et al. (1998) and Vanini et al. (2007). Following interseeding, the experimental area received a starter fertilizer application and siduron, applied at the same rates described for 2007. Topdressing, using the same well-graded, high-sandcontent root zone, was initiated on 14 July 2008, providing 2 -year cumulative topdressing depths of $0.0,1.0$,

Table 2. Cumulative topdressing applications applied to a kentucky bluesgrassperennial ryegrass mixture using a well-graded, high-sand-content root zone (90\% sand, $7.0 \%$ silt, and $3.0 \%$ clay) at the HTRC, East Lansing, MI, in 2007 and 2008.

\begin{tabular}{|c|c|c|c|c|c|c|c|c|c|c|}
\hline \multirow{2}{*}{$\begin{array}{l}\text { Days after initiation } \\
\text { of topdressing }(d)^{z}\end{array}$} & \multicolumn{5}{|c|}{$\begin{array}{l}\text { Topdressing applications } \\
\text { applied in } 2007 \text { (no.) }\end{array}$} & \multicolumn{5}{|c|}{$\begin{array}{l}\text { Topdressing applications } \\
\text { applied in } 2008 \text { (no.) }\end{array}$} \\
\hline & 0 & 2 & 4 & 6 & 8 & 0 & 2 & 4 & 6 & 8 \\
\hline 0 & & $\mathrm{X}^{\mathrm{y}}$ & $X$ & X & $X$ & & $X$ & X & X & $\mathrm{X}$ \\
\hline 2 & & & & & & & & & & $\mathrm{X}$ \\
\hline 4 & & & & & & & & & X & \\
\hline 6 & & & & & X & & & & & $\mathrm{X}$ \\
\hline 8 & & & & X & & & & & & \\
\hline 10 & & & & & $\mathrm{X}$ & & & $\mathrm{X}$ & & \\
\hline 12 & & & $\mathrm{X}$ & & & & & & X & $\mathrm{X}$ \\
\hline 14 & & & & $\mathrm{X}$ & $\mathrm{X}$ & & & & & \\
\hline 16 & & & & & & & & & & \\
\hline 18 & & & & & & & & $\mathrm{X}$ & $\mathrm{X}$ & $\mathrm{X}$ \\
\hline 20 & & & & & $\mathrm{X}$ & & & & & \\
\hline 22 & & & $\mathrm{X}$ & $\mathrm{X}$ & & & & & & \\
\hline 24 & & & & & & & & & & $\mathrm{X}$ \\
\hline 26 & & & & & $\mathrm{X}$ & & & & & \\
\hline 28 & & & & $\mathrm{X}$ & & & & & $\mathrm{X}$ & $X$ \\
\hline 30 & & & & & X & & & & & \\
\hline 32 & & & & & & & & & & \\
\hline 34 & & & & & & & & & & \\
\hline 36 & & $X$ & $\mathrm{X}$ & $\mathrm{X}$ & $\mathrm{X}$ & & & & & \\
\hline 38 & & & & & & & X & X & X & $X$ \\
\hline
\end{tabular}

${ }^{2}$ Topdressing was initiated on 11 July 2007 and 14 July 2008.

Topdressing $2.0 \mathrm{lb} / \mathrm{ft}^{2}(0.25$-inch depth) per application, producing a cumulative topdressing depths of 0.0 to 2.0 inches in 2007 and 0.0 to 4.0 inches in $2008 ; 1 \mathrm{lb} / \mathrm{ft}^{2}=4.8824 \mathrm{~kg} \cdot \mathrm{m}^{-2}, \mathrm{l}$ inch $=2.54 \mathrm{~cm}$.

2.0, 3.0, and 4.0 inches (Table 2), again similar to the topdressing practices that are incorporated on an athletic field with heavy spring and fall use. Similar to the procedures described for 2007, simulated traffic was exercised from 14 Oct. to 12 Nov. 2008.

Site management. Turfgrass was maintained at a height of 3.0 inches, with clippings returned, from 11 July to 27 Aug. 2007 and 2008, to promote rooting and increase heat stress tolerance (Table 3 ) and then reduced to 2.0 inches before fall traffic applications (Vanini and Rogers, 2008). Polymer-coated fertilizer $26 \mathrm{~N}-3.1 \mathrm{P}-11.6 \mathrm{~K}$ (Agrium ${ }^{\circledR}$, Sylacauga, AL) was applied at a rate of $1.0 \mathrm{lb} / 1000 \mathrm{ft}^{2}$ nitrogen (amounting to $3.8 \mathrm{lb} / 1000 \mathrm{ft}^{2}$ fertilizer per application) on 21 June, 18 July, and 15 Aug. 2007 and 15 May, 20 June, 22 July, and 25 Aug. 2008. Urea (46N$0 \mathrm{P}-0 \mathrm{~K})$ was applied at a rate of 0.5 $\mathrm{lb} / 1000 \mathrm{ft}^{2}$ nitrogen (amounting to $1.1 \mathrm{lb} / 1000 \mathrm{ft}^{2}$ fertilizer per application) on 11 and 24 July and 10 and 26 Oct. 2007 and 15 July, 5 Aug., 22 Sept., and 17 Oct. 2008. These application rates combined with the starter fertilizer applied in May 2007 and Apr. 2008 provide 5.6 and 6.6 $\mathrm{lb} / 1000 \mathrm{ft}^{2}$ nitrogen annually in 2007 and 2008, respectively. To provide post-emergence weed control, quinclorac (BASF, Research Triangle Park, NC) was applied at $0.02 \mathrm{lb} /$ $1000 \mathrm{ft}^{2}$ with methylated seed oil $(0.3 \% \mathrm{v} / \mathrm{v})$ on 24 July 2007 , and a three-way broadleaf herbicide, 2,4dichlorophenoxyacetic acid, propionic

Table 3. Mean maximum and minimum monthly temperature and rainfall monitored at the HTRC, East Lansing, MI [lat. $42^{\circ} 42^{\prime} 36^{\prime \prime} \mathrm{N}$, long. 84 $28^{\prime} 48^{\prime \prime} \mathrm{W}, 257.0-\mathrm{m}(843.18$-ft) elevation ] using the Michigan Automated Weather Network weather station (MSU, 2009).

\begin{tabular}{|c|c|c|c|c|c|c|}
\hline \multirow[b]{3}{*}{ Month } & \multicolumn{3}{|c|}{2007 Mean values } & \multicolumn{3}{|c|}{2008 Mean values } \\
\hline & \multicolumn{2}{|c|}{ Temp. $\left({ }^{\circ} \mathbf{F}\right)^{\mathrm{z}}$} & \multirow{2}{*}{$\begin{array}{c}\text { Rainfall } \\
(\text { inch } / \text { mo. })^{y}\end{array}$} & \multicolumn{2}{|c|}{ Temp. $\left({ }^{\circ} \mathrm{F}\right)$} & \multirow{2}{*}{$\begin{array}{c}\text { Rainfall } \\
(\text { inch } / \text { mo. })^{\mathrm{z}}\end{array}$} \\
\hline & Maximum & Minimum & & Maximum & Minimum & \\
\hline Feb. & - & - & - & 30.1 & 14.3 & 1.3 \\
\hline Mar. & - & - & - & 39.8 & 23.6 & 0.8 \\
\hline Apr. & 66.9 & 42.0 & 2.6 & 62.9 & 38.8 & 1.9 \\
\hline July & 81.7 & 58.1 & 0.7 & 80.8 & 59.9 & 3.7 \\
\hline Aug. & 81.2 & 62.0 & 4.7 & 80.3 & 57.5 & 0.5 \\
\hline Sept. & 76.1 & 53.4 & 1.9 & 74.2 & 51.9 & 7.3 \\
\hline Oct. & 66.3 & 47.6 & 3.7 & 59.0 & 37.7 & 1.5 \\
\hline Nov. & 46.1 & 31.0 & 1.3 & 44.2 & 30.8 & 1.0 \\
\hline
\end{tabular}

${ }^{\mathrm{z}}\left({ }^{\circ} \mathrm{F}-32\right) \div 1.8={ }^{\circ} \mathrm{C}, 1$ inch $=2.54 \mathrm{~cm}$.

Research was initiated on 10 Apr. 2007 and concluded 14 Nov. 2008. 
acid, and dicamba (PBI/Gordon, KS City, MO), at a rate of $0.02,0.006$, and $0.002 \mathrm{lb} / 1000 \mathrm{ft}^{2}$, respectively, was applied on 26 July 2007.

RESPONSE VARIABLES. Turfgrass cover, shoot density, and surface shear strength data were collected after the conclusion of the fall traffic period, 10 Nov. 2007, and 14 Nov. 2008. Percentage of living groundcover $(0.0$ $100.0 \%$ ) was based on the National Turfgrass Evaluation Program (NTEP) system of rating (NTEP, 2009). Shoot density per 13.4 inch $^{2}$ was determined by manually counting the shoots from two randomly selected subsamples per $32.0-\mathrm{ft}^{2}$ treatment, collected using a 4.0-inch-diameter cup cutter (Miltona ${ }^{\circledR}$ Turf Products, Maple Gove, MN), then converted and reported in shoots per square foot to facilitate comparison with like research. Samples were returned to their respective treatments after turfgrass shoots were counted. Surface shear strength was evaluated using the $\mathrm{Clegg}^{\odot}$ turf shear tester (TST) with a 50.0 -mm-wide $\times 40.0$ mm-insertion depth paddle (model CCBIA; Baden Clegg, Wembley, WA, Australia), which measures divot resistance (Sherratt et al., 2005), three subsamples per plot.

Statistical analysis. Turfgrass shoot density and TST data were analyzed as a randomized complete block design, with three replications, using SAS $^{\circledR}$ (version 9.2; SAS Institute, Cary, NC). Normality of the residuals and homogeneity of variances were examined using PROC UNIVARIATE procedure. Mean separations were obtained based on the selected analysis using Fisher's least significant difference at a 0.05 level of probability (Ott and Longnecker, 2001). The 2007 and 2008 data were analyzed and displayed separately to evaluate the effects of various topdressing depths accumulated in a single year $(0.0,0.5,1.0,1.5$, and 2.0 inches) and topdressing depths achieved over a 2 -year period $(0.0$, 1.0, 2.0, 3.0, and 4.0 inches).

\section{Results and discussion}

Effects of topdressing depth on percentage of living groundcover and turfgrass shoot density, observed on 10 Nov. 2007 after the application of fall traffic, were not significant (Table 4).

Significant main effects of topdressing depth on fall TST values were observed on 10 Nov. 2007 (Table 4). Mean TST values, or divot resistance, were greatest in the treatments that received 0.5 -inch topdressing depth, the TST values in treatments that received 0.5- and 1.0-inch topdressing depths were not different, and the control (0.0), 1.5-, and 1.0-inch topdressing depths produced the lowest TST values. Baker et al. (2007) observed a similar response, with peak traction at an annual sand topdressing application rate of $8.0 \mathrm{~kg} \cdot \mathrm{m}^{-2}$, and an approximate annual topdressing depth of $0.5 \mathrm{~cm}$. The research conducted by Baker et al. (2007) used perennial ryegrass, a turfgrass species, which has a bunch type growth habit, while kentucky bluegrass, the dominate turfgrass species selected for this research, has a rhizomatous growth habit. The rhizomatous growth habit of the kentucky bluegrass may account for the differences observed between the compared research.

A significant main effect of topdressing depth on turfgrass cover and shoot density was observed in Fall 2008 (Table 5). Turfgrass cover and shoot density were increased by all topdressing depths compared with the non-topdressed control. The 3.0and 4.0-inch topdressing depths provided shoot densities ranking in the greatest category. Similar to these findings, Miller (2008) observed increased bermudagrass stand density, quality, and rooting as a result of sand topdressing at a $0.6-\mathrm{cm}(0.25$-inch $)$ topdressing depth per year. Baker et al. (2007) documented a direct relationship between increased perennial ryegrass cover and annual sand topdressing rates ranging from 0.0 to $12.0 \mathrm{~kg} \cdot \mathrm{m}^{-2}[0.0-$ to $0.7-\mathrm{cm}(0.3-$ inch) topdressing depth, respectively].

Significant main effects of topdressing depth on TST values were also observed in Fall 2008 (Table 5). The control, a sandy loam soil without sand topdressing, produced the greatest overall mean TST values. These findings are likely due to the inherent cohesive nature of the compacted sandy loam soil in comparison with sand (Benson and Daniel, 1990; Bingaman and Kohnke, 1970; Henderson et al., 2005a). Heavy traffic, such as the rates simulated in this research project, on a sandy loam can result in soil compaction, particularly when combined with wet soil conditions (Das, 2006; Lunt, 1956). Soil compaction, while being detrimental to

Table 4. Analysis of variance and mean values for turfgrass (kentucky bluesgrass-perennial ryegrass mixture) shoot density and divot resistance (Clegg turf shear tester strength) following the fall traffic simulator applications, at East Lansing, MI, on 10 Nov. 2007.

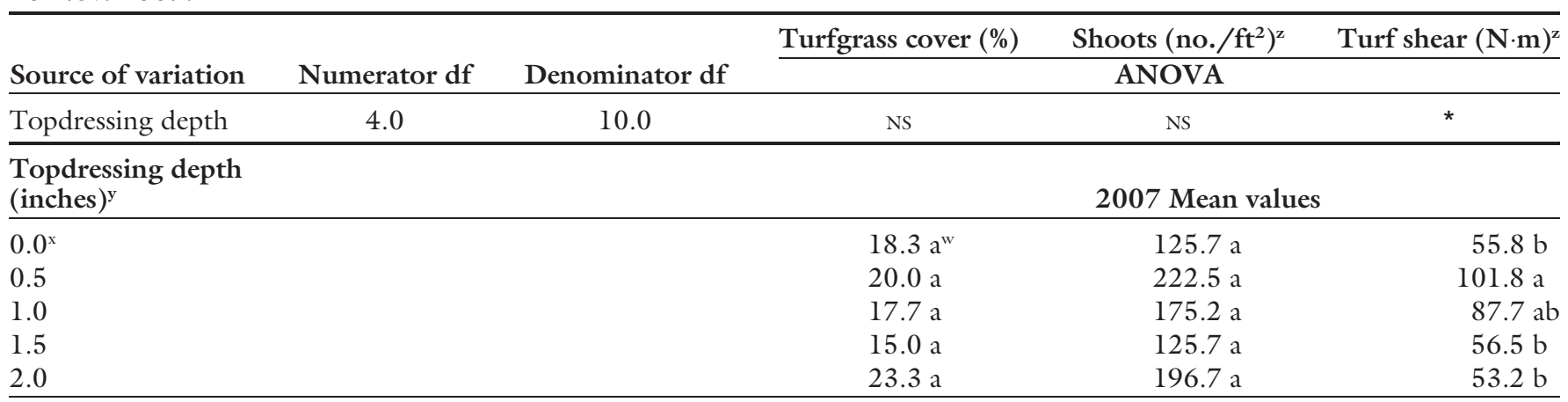

${ }^{\mathrm{z}} 1$ shoot $/ \mathrm{ft}^{2}=10.740$ shoots $/ \mathrm{m}^{2}, 1$ Newton meter $(\mathrm{N} \cdot \mathrm{m})=0.7375 \mathrm{lb} \mathrm{ft}$.

yTopdressing accumulated over a 5 -week period, 11 July to 15 Aug. 2007 ; 1 inch $=2.54 \mathrm{~cm}$.

${ }^{x}$ Number of replications for all other treatments $=3$.

within columns, means followed by the same letter are not significantly different according to least significant difference at $P \leq 0.05$.

Ns, *Nonsignificant or significant at the $P=0.05$ level, respectively. 
Table 5. Analysis of variance and mean values for turfgrass (kentucky bluesgrass-perennial ryegrass mixture) shoot density and divot resistance (Clegg turf shear tester strength) following the traffic simulator applications, at East Lansing, MI, on 14 Nov. 2008.

\begin{tabular}{|c|c|c|c|c|c|}
\hline \multirow[b]{2}{*}{ Source of variation } & \multirow[b]{2}{*}{ Numerator df } & \multirow[b]{2}{*}{ Denominator df } & Turfgrass cover (\%) & Shoots $\left(\text { no. } / \mathrm{ft}^{2}\right)^{\mathrm{z}}$ & Turf shear $(\mathrm{N} \cdot \mathrm{m})^{\mathrm{z}}$ \\
\hline & & & \multicolumn{3}{|c|}{ ANOVA $^{\mathbf{y}}$} \\
\hline Topdressing depth & 4.0 & 10.0 & * & $* * *$ & ** \\
\hline $0.0^{\mathrm{x}}$ & & & $53.3 \mathrm{~b}^{\mathrm{w}}$ & $271.9 \mathrm{c}$ & $130.7 \mathrm{a}$ \\
\hline 3.0 & & & $70.0 \mathrm{a}$ & $669.5 \mathrm{a}$ & $91.3 \mathrm{c}$ \\
\hline 4.0 & & & $70.0 \mathrm{a}$ & $587.8 \mathrm{ab}$ & $80.1 \mathrm{c}$ \\
\hline
\end{tabular}

${ }^{2} \mathrm{l}$ shoot $/ \mathrm{ft}^{2}=10.740$ shoots $/ \mathrm{m}^{2}, \mathrm{l}$ Newton meter $(\mathrm{N} \cdot \mathrm{m})=0.7375 \mathrm{lb} \mathrm{ft}$.

yTopdressing accumulated over a 2-year period, 11 July to 15 Aug. 2007, and 14 July to 22 Aug. $2008 ; 1$ inch $=2.54 \mathrm{~cm}$.

${ }^{x}$ Number of replications for all other treatments $=3$.

within columns, means followed by the same letter are not significantly different according to least significant difference at $P \leq 0.05$.

$*, * *, * *$ Significant at $0.05,0.01$, and 0.001 levels of probability, respectively.

turfgrass health and vigor (Carrow, 1980; Vanini et al., 2007), could account for the increased shear strength observed in this project. Mouazen et al. (2002) observed increased cohesion, or shear strength, on a sandy loam-textured soil as bulk density, or compaction, increased, which could help explain why the control provided the greatest TST strength after 2 years (consecutive) of traffic. The hypothesis that increased TST strength is a result of the soil physical characteristics is only reinforced by the low shoot density results observed within the control and work by Kowalewski (2010), which showed no differences in rooting density between treatments that received topdressing at the depths defined in this research and treatments that were not topdressed.

While the control produced the greatest mean TST values in 2008 , it produced TST values ranking in the lowest category in 2007. Elevated rainfall levels were observed during the fall traffic period in 2007, 3.7 inches over the month of October (MSU, 2009) (Table 3), in comparison with the 1.5 inches observed over the Oct. 2008 traffic period. Mouazen et al. (2002) also determined that plasticity increases and shear strength decreases as the moisture content of a sandy loam soil increases. The differences in rainfall observed throughout the fall traffic period, and the effects of soil moisture on the mechanical properties of a sandy loam soil, may explain why the control possessed the lowest ranking TST strength in 2007, but the highest TST strength in 2008.
Mean TST values were the lowest in 2008 with accumulated topdressing depths of 2.0,3.0, and 4.0 inches (Table 5). Sherratt et al. (2005) produced TST strength results (70.0 to $95.0 \mathrm{~N} \cdot \mathrm{m}$ ) comparable to our findings in kentucky bluegrass sod established on a high-sand-content root zone (87.5\% sand). This work may suggest that the TST strength results observed within the 2.0-, 3.0-, and 4.0-inch topdressing depth treatments are within the range of anticipated values for a sand-based system, whether it be a sand-based system by design or a turfgrass system amended with sand-based sod or sand topdressing. Spring et al. (2007) observed reduced traction at the highest sand topdressing rate [12.0 $\mathrm{kg} \cdot \mathrm{m}^{-2}(0.7-\mathrm{cm}$ deep $)$ per year]. The 1.0-inch topdressing depth accumulated over two consecutive summers increased TST values in comparison with topdressing depths of 2.0,3.0, and 4.0 inches. Baker et al. (2007) observed reduced shear strength within treatments topdressed with sand at rates greater than $8.0 \mathrm{~kg} \cdot \mathrm{m}^{-2}(0.5$-inch topdressing depth) per year. While topdressing at the 3.0- and 4.0-inch depths over two consecutive summers reduced TST strength, these depths provided the highest ranking shoot densities, which would imply greater long-term playability.

A total topdressing depth of 1.0 inch $\left[8.0 \mathrm{lb} / \mathrm{ft}^{2}\left(39.2 \mathrm{~kg} \cdot \mathrm{m}^{-2}\right)\right]$ applied over a 2-year period provided the optimum results, a combination of turfgrass cover, shoot density, and divot resistance (Table 5). Baker and Canaway (1992) and Spring et al. (2007) showed that the greatest sand topdressing rates used in their research, 12.0 and $16.0 \mathrm{~kg} \cdot \mathrm{m}^{-2}$ per year (approximate annual topdressing depths of 0.3 and 0.4 inches, respectively), provided the optimum playing quality, perennial ryegrass cover, soccer ball bounce and rebound resilience, traction, and surface hardness. Baker and Canaway (1992) even suggested that the optimum topdressing rate for a sandy loam-textured soil or heavier maybe greater than the rates used in their research.

TST values in 2008 (Table 5) were greater than those observed in 2007 (Table 4), likely as the result of accumulated sand and a year of turfgrass growth and development. Rogers et al. (1998) also observed increased turfgrass cover in the second year of data, likely due to the effects of the development and maturation of a kentucky bluegrass-perennial ryegrass mixture seeded 3 years ago. Vanini et al. (2007) observed greater shear resistance in the second year of data collection on a kentucky bluegrass stand that received traffic for 2 years. These findings and the results observed in this research suggest that overall turfgrass strength will increase as a turfgrass system matures.

\section{Literature cited}

ASTM International. 2006. Standard practice for classification of soils for engineering purposes (unified soil classification system). ASTM International D 2487-06:1-11. ASTM International, West Conshohocken, PA.

Baker, S.W. and P.M. Canaway. 1992. The effects of sand topdressing on the 
performance of winter games pitches of different construction types. II. Playing quality. J. Sports Turf Res. Inst. 68:62-72.

Baker, S.W., C.A. Spring, and J.A. Wheater. 2007. Fertiliser, sand topdressing and aeration programmes for football pitches. II. Cost-effectiveness of management strategies. J. Turfgrass Sports Surface Sci. 83:56-67.

Barton, L., G.G.Y. Wan, R.P. Buck, and T.D. Colmer. 2009. Effectiveness of cultural thatch-mat controls for young and mature kikuyu turfgrass. Agron. J. 101: 67-74.

Beard, J.B. 1978. Topdressing overview. Proc. 48th Annu. Mich. Turfgrass Conf. 7:36-39.

Benson, C.H. and D.E. Daniel. 1990. Influence of clods on the hydraulic conductivity of compacted clay. J. Geotech. Eng. 116:1231-1248.

Bingaman, D.E. and H. Kohnke. 1970. Evaluating sand for athletic turf. Agron. J. 62:464-467.

Brede, A.D. and J.M. Duich. 1984. Establishment characteristics of kentucky bluegrass-perennial ryegrass turf mixtures as affected by seeding rate and ratio. Agron. J. 76:875-879.

Canaway, M. 1976. A differential slip wear machine (d.s.i.) for artificial simulation of turfgrass wear. J. Sports Turf Res. Inst. 52:92-99.

Carrow, R.N. 1980. Influence of soil compaction on three turfgrass species. Agron. J. 72:1038-1042.

Das, B.M. 2006. Principles of geotechnical engineering. 6th ed. Thomson, Southbank, Australia.

Henderson, J.J., J.R. Crum, T.F. Wolf, and J.N. Rogers. 2005a. Effects of particle size distribution and water content at compaction on saturated hydraulic conductivity and strength of high sand content root zone materials. Soil Sci. 170: 315-324.

Henderson, J.J., J.L. Lanovaz, J.N. Rogers, III, J.C. Sorochan, and J.T. Vanini. 2005b. A new apparatus to simulate athletic field traffic: The cady traffic simulator. Agron. J. 97:1153-1157.

Kowalewski, A.R. 2010. The built-up sand-capped athletic field system. Michigan State Univ., East Lansing, MI, PhD Diss.

Liebao, H. and D.E. Aldous. 1999. Turfgrass establishment, revegetation and renovation, p. 81-100. In: D.E. Aldous (ed.). International turf management handbook. Inkata Press, Melbourne, Australia.

Lunt, O.R. 1956. A method for minimizing compaction in putting greens. South. Calif. Turfgrass Cult. 6:17-20.

McCarty, L.B., M.F. Gregg, J.E. Toler, J.J. Camberato, and H.S. Hill. 2005. Minimizing thatch and mat development in a newly seeded creeping bentgrass golf green. Crop Sci. 45:1529-1535.

Michigan State University. 2009. MAWN: Michigan automated weather network. 20 Nov. 2009. <http://www. agweather.geo.msu.edu/mawn $/>$.

Miller, G.L. 2008. An evaluation of crumb rubber and calcined clay for topdressing sports fields. Acta Hort. 783: 381-390.

Mouazen, A.M., H. Ramon, and J.D. Baerdemaeker. 2002. Effects of bulk density and moisture content on selected mechanical properties of sandy loam soil. Biosyst. Eng. 83:217-224.

National Turfgrass Evaluation Program. 2009. A guide to NTEP turfgrass ratings.
24 Apr. 2009. <http://www.ntep.org/ reports/ratings.htm>.

Natural Resources Conservation Service. 2007. Web soil survey. 24 Apr. 2009. <http://websoilsurvey.nrcs.usda.gov/ app/WebSoilSurvey.aspx>

Ott, R.M. and M. Longnecker. 2001. An introduction to statistical methods and data analysis, 5th ed. Duxbury, Pacific Grove, CA.

Puhalla, J., J. Krans, and M. Goatley. 1999. Sports fields: A manual for design, construction and maintenance. Ann Arbor Press, Chelsea, MI.

Rogers, III, J.N., J.T. Vanini, and J.R. Crum. 1998. Simulated traffic on turfgrass topdressed with crumb rubber. Agron. J. 90:215-221.

Sherratt, P.J., J.R. Street, and D.S. Gardner. 2005. Effects of biomass accumulation on the playing quality of a kentucky bluegrass stabilizer system used for sports fields. Agron. J. 97:1107-1114.

Spring, C.A., J.A. Wheater, and S.W. Baker. 2007. Fertiliser, sand topdressing and aeration programmes for football pitches. I. Performance characteristics under simulated wear. J. Turfgrass Sports Surf. Sci. 83:40-55.

Vanini, J.T., J.J. Henderson, J.C. Sorochan, and J.N. Rogers, III. 2007. Evaluating traffic stress by the brinkman traffic simulator and cady traffic simulator on a kentucky bluegrass stand. Crop Sci. 47:780784 .

Vanini, J.T. and J.N. Rogers, III. 2008. Mowing strategies and fertilization improves sports fields during and after 70day re-establishment window. Appl. Turfgrass Sci. (Online), p. 1-10. 23 Apr. 2009. $<$ http://www.plantmanagementnetwork. org/pub/ats/research/2008/70day/>. 